University of Nebraska - Lincoln

DigitalCommons@University of Nebraska - Lincoln

Publications from USDA-ARS / UNL Faculty

U.S. Department of Agriculture: Agricultural

Research Service, Lincoln, Nebraska

2004

Registration of Three Partial Waxy Winter Wheats

Robert A. Graybosch

University of Nebraska-Lincoln, bob.graybosch@ars.usda.gov

P. Stephen Baenziger

University of Nebraska-Lincoln, pbaenziger1@unl.edu

Follow this and additional works at: https://digitalcommons.unl.edu/usdaarsfacpub

Part of the Agricultural Science Commons

Graybosch, Robert A. and Baenziger, P. Stephen, "Registration of Three Partial Waxy Winter Wheats" (2004). Publications from USDA-ARS / UNL Faculty. 908.

https://digitalcommons.unl.edu/usdaarsfacpub/908

This Article is brought to you for free and open access by the U.S. Department of Agriculture: Agricultural Research Service, Lincoln, Nebraska at DigitalCommons@University of Nebraska - Lincoln. It has been accepted for inclusion in Publications from USDA-ARS / UNL Faculty by an authorized administrator of DigitalCommons@University of Nebraska - Lincoln. 


\section{Registration of Three Partial Waxy Winter Wheats}

96MD7413-58 (Reg. no. GP-773, PI 617069), 96MD741336 (Reg. no. GP-774, PI 617070), and 96MD7110-71 (Reg. no. GP-775, PI 617071) partial waxy (reduced amylose) hard winter wheat (Triticum aestivum L.) germplasm lines were released by the ARS, USDA, and the Nebraska Agricultural Experiment Station in November 2002.

These partial waxy wheats carry non-functional (null) alleles $(W x-A 1 b$ and $W x-B 1 b)$ at two of the three hexaploid wheat $W x$ loci. These loci encode isoforms of the enzyme granule-bound starch synthase (GBSS, EC 2.4.1.21), also known as the "waxy" protein. Wheats with nonfunctional alleles at two loci are known as "double-nulls." Double-null partial waxy wheats produce endosperm starch with reduced amylose content, relative to that of single-null or wild-type wheats. Such starch confers unique functional properties to derived wheat flour. Suggested uses for partial waxy wheats include a novel source for the production of modified food starches, and a blending agent to create flours with optimal amylose concentration for the production of a variety of sheeted and baked food products (Epstein et al., 2002; Graybosch, 1998). Partial waxy wheats also are useful as donors of the $W x$ null alleles for the breeding of completely waxy (amylose free, triple null) lines. Crosses between double-null partial waxy wheats and completely waxy wheats will result in populations composed of $25 \%$ waxy individuals. In comparison, populations derived from crosses between wild-type wheat and waxy wheat will produce waxy progeny at a frequency of only $1 / 64$.

96MD7413-58 and 96MD7413-36 were both descended from the cross NE90616/'Ike', while 96MD7110-71 was derived from MT8713/NE87612//Ike. Ike ('Dular'/'Eagle'//2*'Cheney'/ 'Larned' $/ 3 /{ }^{\circ}$ Colt') is the source of the double-null trait for all three lines. Ike is a hard red winter wheat released by the Kansas Agricultural Experiment Station in 1994. To date, Ike is the only known double-null partial waxy wheat cultivar released for cultivation in North America, and in 2003, was seeded on approximately $2 \%$ of the total wheat acreage in Kansas (http://www.nass.usda.gov/ks/whtvar/whtvar03.pdf; verified 17 June 2004). NE90616 ('Arapahoe'/Colt 83 composite) is a hard winter wheat breeding line developed by the University of Nebraska. Colt 83 composite was an unreleased reselection from the cultivar Colt. NE87612 ('Newton'/'Warrior' 5*/'Agent'/3/NE69441) also is a hard winter wheat breeding line from the University of Nebraska. The pedigree of NE69441 was 'Ponca'/3*'Cheyenne'/3/'Kenya58'/'Newthatch'/ $2 / 2 * \mathrm{CTMH} / 4 /$ 'Scout'. The pedigree of CTMH is Cheyenne'Tenmarq'-'Mediterranean'-'Hope' where the order of the 
crosses is unknown. MT8713 (PI 564762), ('Roughrider'//TX 55-391-56-D8/'Westmont'), a sib line of the cultivar Erhardt, is a hard red winter wheat breeding line developed by Montana State University. TX55-391-56-D8 was descended from 'Sinvalocho'/'Wichita'//'Hope'/'Cheyenne'/3/Wichita/4/'Seu Seun 27'.

The three germplasm lines were developed as follows: $F_{1}$ plants were grown in the greenhouse at Lincoln, NE. $F_{2}$ and $\mathrm{F}_{3}$ populations were seeded at Mead, NE, in 1994 and 1995 , respectively. No selection other than winter-survival was exercised during the $F_{2}$ and $F_{3}$ generations. In 1996, head selections were made from $\mathrm{F}_{3}$ bulk populations grown at Mead, NE. Starch was purified from a bulk sample of 8 seed per head; starch-granule proteins were purified and separated by gel electrophoresis as described by Nakamura et al. (1995) to identify $w x$ loci genotypes. The $w x$ genotypes are easily identified by electrophoretic migration patterns of the waxy protein isoforms. Remnant seed of each head was seeded in unreplicated rows at Berthoud, CO, in February 1997. Each line was selected from a single $\mathrm{F}_{3: 4}$ rows. The release of these partial waxy lines expands the number of available genetic backgrounds carrying the double-null trait in wheat.

In crop year 1998, starch amylose concentrations of 96MD7413-58, 96MD7413-36, and 96MD7110-71, based on means from two environments, were 184,184 , and $179 \mathrm{~g} \mathrm{~kg}^{-1}$, respectively. In comparison, amylose concentrations of Ike (double-null), 'TAM-202' ( $w x-B 1 b$, single null), 'Redland' (wild type) and 'Vista' (wild type) were 189, 212, 233, and $237 \mathrm{~g} \mathrm{~kg}^{-1}$, respectively. In replicated yield trials in 4 Nebraska environments over the 1999 and 2000 crop years, grain yields of 96MD7413-58, 96MD7413-36, and 96MD7110-71 averaged 2822,2859 , and $2675 \mathrm{~kg} \mathrm{ha}^{-1}$, respectively. In the same environments, the check cultivars Arapahoe, Ike, Redland, TAM202, and Vista averaged 2344, 2990, 2709, 2920, and $2706 \mathrm{~kg} \mathrm{ha}^{-1}$, respectively. Respective volume weights of 96MD7413-58, 96MD7413-36, and 96MD7110-71 were 66.6, 76.3, and $69.7 \mathrm{~kg}$ $\mathrm{hL}^{-1}$, as opposed to volume weights of $65.5,77.3,64.5,74.2$, and $71.1 \mathrm{~kg} \mathrm{hL}^{-1}$ for Arapahoe, Ike, Redland, TAM202 and Vista. 96MD7413-58, 96MD7413-36, and 96MD7110-71 were entered in the USDA-ARS coordinated Northern Regional Performance Nursery (NRPN) in 2001. Over 12 production environments in the northern Great Plains in 2001, respective mean grain yields of 96MD7413-58, 96MD7413-36, and 96MD7110-71 were 4035, 3849, $3853 \mathrm{~kg} \mathrm{ha}^{-1}$, as opposed to respective grain yields of $3921,3857,3952 \mathrm{~kg} \mathrm{ha}^{-1}$ for the check cultivars 'Abilene', 'Nekota', and 'Trego'. Volume weights of grain harvested from 2001 trials of 96MD7413-58, 96MD741336 , and 96MD7110-71 were 72.9, 74.6, and 77.2 $\mathrm{kg} \mathrm{hL}^{-1}$, as opposed to volume weights of $77.7,75.8$, and $78.1 \mathrm{~kg} \mathrm{hL}^{-1}$ for the check cultivars Abilene, Nekota, and Trego. Over the same production environments, plant heights of 96MD741358, 96MD7413-36, and 96MD7110-71 averaged 75, 76, and $69 \mathrm{~cm}$, respectively. Average respective plant heights of Abilene, Nekota, and Trego were 66, 71, and $69 \mathrm{~cm}$. Average respective days (from January 1st) to heading for 96MD741358, 96MD7413-36, 96MD7110-71, Abilene, Nekota, and Trego were $159,159,158,158,158$, and 158 . On the basis of observations from nine 2001 production environments in the northern Great Plains, 96MD7413-58 and 96MD7413-36 are less winter hardy than Abilene, Nekota, and Trego while 96MD7110-71 is more winter hardy than Abilene and Nekota, and equal to Trego. All three germplasm lines are intolerant of acid soils.

White salted noodle quality of 96MD7413-58, 96MD741336, and 96MD7110-71 was tested on samples from three environments harvested in 2000. Relative to Arapahoe, Redland, and TAM202, all three produce softer-textured cooked noodles, equal in softness to that of Ike. Color stability, as measured by changes over $24 \mathrm{~h}$ in Minolta Colorimeter (Chroma
Meter CR-210, Minolta Camera Co. Ltd, Osaka, Japan) L* (brightness), $\mathrm{a}^{*}$ (redness), and $\mathrm{b}^{*}$ (yellowness) values, from all three lines was similar to that of Arapahoe, Redland, and TAM202, but slightly less stable than that of Ike. Additional quality testing of samples of 96MD7413-58, 96MD7413-36, and 96MD7110-71 from the 2001 NRPN revealed that sound grain from all three lines had significantly lower stirring numbers (as determined by the Rapid Visco Analyser), than all other entries. The lower stirring numbers indicate altered starch cooking properties. 96MD7413-58 and 96MD7413-36 produce stronger doughs than the NRPN check cultivar Abilene, while dough strength of 96MD7110-71 is slightly weaker than that of Abilene. Loaf volumes of all three lines are similar to Abilene, but all three also produce loaves with less desirable internal appearance (loaf grain). The poor loaf grain is related to the altered starch properties, and suggests that partial waxy wheats, if cultivated for their unique starches, should be separated in marketing channels from typical hard winter wheats.

96MD7413-58, 96MD7413-36, and 96MD7110-71 are red seeded, hard grained, awned, winter wheats. All three are heterogeneous for unidentified resistance genes to Hessian fly (Mayetiola destructor Say), but are susceptible to greenbug (Schizaphis graminum Rondani) and Russian wheat aphid (Diuraphis noxia Mordvilko). All three also are moderately resistant to present prevalent races of stem rust (caused by Puccinia graminis Pers.: Pers.). 96MD7413-58 and 96MD741336 are postulated to carry $\operatorname{Sr} 6, \operatorname{Sr} 17$, and $S r 24$, while 96MD7110-71 is postulated to carry $\operatorname{Sr} 17$ and $S r 36$. All three are susceptible to common races of leaf rust (caused by Puccinia recondita Roberge ex Desmaz.). 96MD7413-58 has some tolerance to infection by Wheat soilborne mosaic virus, while the other two lines are moderately susceptible.

Seed of all lines has been deposited in the USDA National Small Grains Collection, Aberdeen, ID. Small quantities of seed may be obtained from R. Graybosch, USDA-ARS, University of Nebraska, Lincoln, NE 68583. It is requested that the source of this material be acknowledged in future usage by wheat breeding and genetics programs.

\section{R.A. Graybosch* and P.S Baenziger}

\section{Acknowledgments}

The authors wish to acknowledge the assistance of John Moffatt, Agripro Wheat, and Nancy Ames, Agriculture and Agrifood, Canada.

\section{References}

Epstein, J., C.F. Morris, and K.C. Huber. 2002. Instrumental texture of white salted noodles prepared from recombinant inbred lines of wheat differing in the three granule bound starch synthase (Waxy) genes. J. Cereal Sci. 35:39-50.

Graybosch, R.A. 1998. Waxy wheats: Origin, properties and prospects. Trends Food Sci. Technol. 9:135-142.

Nakamura, T., M. Yamamori, H. Hirano, S. Hidaka, and T. Nagamine. 1995. Production of waxy (amylose-free) wheats. Mol. Gen. Genet. 248:253-259.

R.A. Graybosch, USDA-ARS, 344 Keim, University of Nebraska, Lincoln, NE, 68583; P. Stephen Baenziger, Department of Agronomy \& Horticulture, University of Nebraska, Lincoln. Joint contribution of the United States Department of Agriculture, Agriculture Research Service and the University of Nebraska Agriculture Research Division as Journal Series Paper no. 14472. Registration by CSSA. Accepted 31 May 2004. *Corresponding author (rag@unlserve. unl.edu).

Published in Crop Sci. 44:2273-2274 (2004). 